\title{
IDENTIFIKASI SIKAP IMPLIKASI SOSIAL DARI IPA, KETERTARIKAN MENAMBAH WAKTU BELAJAR IPA, DAN KETERTARIKAN BERKARIR DIBIDANG IPA SISWA SMP SE- KABUPATEN MUARO JAMBI \\ Astalini ${ }^{1}$, Dwi Agus Kurniawan $1^{2}$, Aqina Deswana Putri $2^{3}$ \\ Universitas Jambi, Program Studi Pendidikan Fisika Universitas Jambi \\ Email: astalinizakir@unja.ac.id
}

\begin{abstract}
The purpose of this study is to find out how the attitudes of middle school students towards science in the three indicators adopted from TOSRA are the social implications of science, interest in increasing science time, interest in a career in science. The sample used was 2815 students from the total. This type of research is survey research. The instrument used is an attitude questionnaire. Data analysis in this study uses descriptive statistics. The results obtained show that the three dimensions of the measured attitude have no relevant links, this is due to several factors that influence it. The factors is can be from teacher and technology.
\end{abstract}

Key Words: Attitudes, Natural Science, social implications of Natural Sciences, increasing time to study Natural Sciences, career in Natural Sciences .

\begin{abstract}
ABSTRAK
Tujuan dari penelitian ini untuk mengetahui bagaimana sikap siswa SMP terhadap IPA pada tiga indikator yang diadopsi dari TOSRA yaitu implikasi sosial dari IPA, ketertarikan menambah waktu belajar IPA, ketertarikan berkarir dibidang IPA. Sampel yang digunakan sebanyak 2815 siswa dari total keseluruhan. Jenis penelitian adalah penelitian survei. Instrumen yang digunakan berupa angket sikap. Analisis data pada penelitian ini menggunakan statistik deskriptif. Hasil penelitian yang diperoleh menunjukkan tiga dimensi sikap yang diukur tidak memiliki kaitan yang relevan, hal ini disebabkan oleh beberapa faktor yang berpengaruh di dalamnya. Faktor tersebut salah satunya adalah faktor guru pengampu IPA dan faktor perkembangan teknologi.
\end{abstract}

Kata Kunci: Sikap, IPA, implikasi sosial IPA, menambah waktu belajar IPA, berkarir dibidang IPA

\section{PENDAHULUAN}

Pendidikan sangat berperan penting dalam kehidupan, karena dengan adanya pendidikan seseorang mampu menem-patkan dirinya dengan layak di lingkungan keluarga maupun masyarakat. Hal tersebut mengharuskan pendidikan agar terus di kembangkan secara terus menerus sesuai dengan perkembangan zaman. Tujuan pendidikan di Indonesia dilakukan secara interaktif, inspiratif, dan memotivasi peserta didik untuk meningkatkan sumber daya yang beriman, bertakwa, berbudi pekerti, berdisiplin, bertanggungjawab, serta memiliki kecerdasan intelektual yang tinggi Damanik (2013). Tujuan ini dapat tercapai apabila didukung beberapa faktor yang mempengaruhi di antaranya seperti kualitas pengajaran, metode pengajaran yang di pergunakan, bahan ajar yang digunakan, penyusunan materi, serta kurikulum yang digunakan. Pencapaian potensi pendidikan tersebut dapat diperoleh melalui lembaga pendidikan salah satunya Sekolah Menengah Pertama (SMP). Pada tingkatan ini siswa sudah 
mulai sedikit demi sedikit mampu mengendalikan dirinya dalam berpikir secara ilmiah. Sebagai pengembangan pola pikir peserta didik maka mata pelajaran yang terkait adalah Ilmu Pengetahuan Alam (IPA). Melalui IPA dapat diperoleh kemampuan siswa dalam melakukan eksperimen, pengamatan, dan teori yang memberikan penjelasan mengenai gejala-gejala yang ada dalam kehidupan sehari-hari Indriati (2012).

Pendidikan IPA adalah bagian dari materi pendidikan formal yang mampu memberikan kontribusi kepada sumber daya manusia yang berkualitas Putri (2014). Pembelajaran IPA bukan hanya sebagai wadah penguasaan sejumlah pengetahuan, tetapi juga harus menyediakan ruang yang cukup untuk dapat menerapkannya dalam kehidupan sehari. Pendidikan IPA sampai saat ini masih belum menunjukkan hasil yang memuaskan meskipun telah diperkenalkan sejak peserta didik duduk di bangku Sekolah Dasar (SD). Faktanya pembelajaran IPA saat ini di tekuni oleh siswa agar dapat nilai terbaik saja tanpa mengetahui makna dari pembelajaran IPA itu sendiri. Akibatnya siswa hanya menghafalkan konsep-konsep, teori-teori maupun rumusrumus yang telah diajarkan oleh guru di sekolah Widiadnyana (2014). Artinya peserta didik masih tidak mampu dalam menerapkan pengetahuan serta memahaminya agar dapat bermanfaat dalam kehidupan sehari-hari. Anggapan sebagian peserta didik mengenai pembelajaran IPA menyatakan hal yang di berikan guru di kelas itu hal yang membosankan dan IPA adalah pelajaran yang sulit dipahami. Sejalan dengan yang disampaikan oleh Dinatha (2017) salah satu penyebab kurang pemahaman siswa mengenai IPA karena banyak mempelajari hal-hal yang abstrak. Permasalahan ini didukung oleh Astuti,dkk (2012) mengatakan pembelajaran IPA itu sulit dan hanya mampu dikerjakan oleh siswa yang pintar dan anggapan pembelajaran IPA itu membosankan hampir seluruh siswa menyetujui hal tersebut. Sikap suka dan tidak suka peserta didik terhadap IPA hal ini berpengaruh terhadap proses dan hasil pembelajaran siswa. Keberhasilan dapat dilihat dari perubahan sikap dan tingkah laku siswa terhadap mata pelajaran tersebut Widoyoko (2016).

Sikap peserta didik terhadap IPA merupakan salah satu tindakan peserta didik dalam pembelajaran IPA. Menurut Kena (2016) meningkatnya sikap positif ataupun negatif peserta didik terhadap IPA terbentuk dari pendidikan dasar, sehingga dapat dilihat dampak dari sikap yang diperolah sangat berpengaruh pada latar belakang pendidikan peserta didik. Hasil penelitian yang dilakukan oleh Liaghatdar (2012) menunjukkan pelajaran IPA itu penting. Sikap siswa merupakan salah satu kunci dalam pembelajaran IPA. Tumbuh-nya sikap positif terhadap IPA dapat meningkatkan minat peserta didik terkait profesi sains. Ketika siswa memiliki sikap yang positif terhadap IPA maka segala kinerja akan mendapatkan hasil yang optimal Godwin (2015). Sedangkan jika siswa memiliki sikap yang negatif terhadap IPA akan menimbulkan sikap yang cenderung malas dan tidak termotivasi untuk ikut dalam pembelajaran IPA, Siswa akan mengantuk, dan tidak memiliki komitmen yang kuat dalam pembelajaran IPA. Hasil penelitian juga menunjukkan bahwa pembelajaran IPA itu sangat penting. Sikap siswa terhadap IPA merupakan salah satu kunci dalam pembelajaran IPA. Tumbuhnya sikap positif terhadap IPA dapat meningkatkan minat, motivasi dalam IPA dan berprofesi terkait IPA Liaghatdar (2012). Berdasar-kan permasalahan dimensi sikap IPA dapat di ukur menggunakan dimensi yang diadopsi dati TOSRA milik Fraser (1981) yaitu: 1) implikasi sosial dari mata pelajaran IPA, 2) ketertarikan memper-banyak waktu belajara IPA, 3) ketertarikan berkarir dalam bidang IPA.

Dimensi implikasi sosial dari IPA akan lebih bermakna jika peserta didik 
dapat mengendalikan dirinya dalam pencapaian tujuan dari pendidikan. Dengan kata lain dimensi implikasi sosial dari IPA ini mengkaji bagaimana sikap siswa secara mandiri dalam pembelajaran, hal ini dapat diukur ketika siswa melakukan pema-haman dalam konsep materi, melakukan eksperimen, keaktifan dalam kelas, aktif dan tidak menganggap bahwa IPA adalah salah satu musuh terbesar di sekolah. Peran guru di sini memberikan arahan, memotivasi, dan mengamati bagaimana perkembangan siswa mengenai implikasi terhadap IPA. Dimensi ini juga dapat memberikan dampak positif bagi siswa, karena siswa dapat lebih mandiri dan memiliki pemikiran ilmiah yang tinggi. Ketika siswa mampu mengimplikasi IPA dalam kehidupan sehari-hari tentu saja siswa akan menginginkan waktu yang lebih dalam memahami pembelajaran IPA.

Implikasi dan ketertarikan menambah waktu dalam memahami pembelajaran IPA memiliki keterkaitan satu sama lainnya. menurut Sandi (2012) penam-bahan waktu belajar bagi siswa memungkinkan siswa dapat meningkatkan penguasaan materi pelajaran dengan mengulang kembali pembelajaran yang diperoleh di kelas secara mandiri di rumah, melatih soal-soal baik secara individu maupun berkelompok. Peranan guru yang mendorong siswa untuk dapat berpikir secara mandiri akan menimbulkan sikap positif yang dimiliki oleh siswa. Menurut Chopra (2013) pengaruh positif terhadap mata pelajaran IPA diperoleh dari materi yang diajarkan, metode dan media yang digunakan guru dalam mengajar sehingga dapat mendukung siswa dalam menikmati pelajaran yang di berikan. Sikap positif seperti mengetahui pentingnya pembelajaran IPA dalam kehidupan sehari-hari akan menjadi motivasi bagi peserta didik untuk mencapai tujuan sekaligus menggali kemauan peserta didik dalam belajar di kelas Nordin (2011). Selanjutnya dengan adanya kesenangan peserta didik dalam mengikuti pelajaran IPA di kelas, maka akan mendorong siswa untuk menambahkan waktu belajar terkait dengan IPA.

Berdasarkan hal tersebut, jika siswa sudah memiliki implikasi sosial yang tinggi terhadap pembelajaran IPA serta keinginan menambah waktu belajar IPA maka selanjutnya akan menetap dan melanjutkan karirnya dalam bidang IPA juga. Ketertarikan untuk melanjutkan karir dibidang IPA tidak lepas dari seberapa besar individu tersebut memiliki keyakinan bahwa berkarir dibidang IPA merupakan salah satu keinginan untuk masa depannya. Sehubungan dengan itu, Crumb (2010) mengatakan. "keberhasilan itu dapat diartikan sebagai seberapa besar kebaikan siswa dalam melakukan seluruh tugasnya tanpa membuang waktu". Dengan kata lain, ketertarikan berkarir dalam bidang IPA dapat meningkatkan sikap Siswa terhadap IPA, tetapi tidak semua siswa memilih berkarir dibidang IPA. Bang \& Backer(2013) berpendapat bahwa "siswa laki-laki lebih cenderung dalam memilih karir di bidang IPA, berbeda dengan perempuan masih ada beberapa memiliki sikap negatif terhadap pelajaran IPA". Hacieminoglu (2016) mengatakan bahwa penerapan kurikulum dan teknologi yang digunakan guru dalam mengajar serta lingkungan siswa yang berubah-ubah menjadi faktor timbulnya perasaan negatif terhadap IPA.

Kurangnya pengetahuan dari guru mengenai lemahnya sikap siswa terhadap mata pelajaran IPA memperparah keadaan di mana sikap negatif siswa terhadap IPA akan meningkat. Guido (2013) mengatakan sikap negatif terhadap sains yang dimiliki siswa akan mempengaruhi tidak sukanya siswa pada mata pelajaran sains dan guru yang mengajar sains. Sedangkan sikap positif terhadap mata pelajaran IPA harus dimiliki oleh setiap siswa, karena sikap positif terhadap IPA mempengaruhi perasaan siswa, pemahaman siswa, serta perilaku siswa terhadap mata pelajaran IPA. Pendapat ini dijelaskan oleh Veloo (2015) yang 
mengatakan bahwa "sikap merupakan gambaran dari setiap jenis reaksi manusia yaitu dalam komponen utama yaitu emosi, kognitif dan perilaku seseorang terhadap sesuatu hal". Godwin (2015) sikap individu yang mengarah ke dalam ranah afektif dapat di ubah-ubah untuk mengetahui apakah komponen kognitif dapat menghasilkan hasil yang optimal. Hal ini menunjukkan pentingnya seorang guru untuk dapat mengamati dan menganalisis bagaimana sikap dalam diri siswa mengenai mata pelajaran IPA, sehingga siswa dapat semangat dan ikut berpartisipasi dalam setiap pembelajaran.

Tujuan penelitian diharapkan dapat mempermudah guru dalam mengetahui kendala dan masalah yang dihadapi sikap siswa pada saat belajar IPA. Dalam penelitian ini, pertanyaan yang ditujukan yakni:

1. Deskripsi indikator sikap terhadap mata pelajaran IPA?

2. Apa pendapat siswa mengenai sikap terhadap mata pelajaran IPA?

3. Masalah apa yang dihadapi siswa mengenai sikap terhadap mata pelajaran IPA?

4. Apakah solusi yang dapat dilakukan dalam meningkatkan sikap siswa terhadap mata pelajaran IPA?

Temuan penelitian ini dapat berkontribusi dalam meningkatkan sikap positif siswa terhadap mata pelajaran IPA di lembaga pendidikan Sekolah Menengah Pertama, terutama di Indonesia dan negara-negara lainnya. Hal ini dapat di lihat pada SMP yang ada di Kabupaten Muaro Jambi yang memiliki kendala terhadap siswa yakni sikap negatif terhadap mata pelajaran IPA. Penelitian

\section{Instrumen dan prosedur}

Ada 2 instrumen yang digunakan adalah angket dan wawancara. Instrumen angket yang digunakan jenis tertutup, berjumlah 54 pernyataan yang memaparkan sikap positif dan negatif siswa ini nantinya yang bertujuan untuk membantu guru dalam mening-katkan pemahaman siswa dan prilaku siswa terhadap mata pelajaran IPA di sekolah.

\section{METODE PENELITIAN}

\section{Desain penelitian}

Jenis penelitian yang digunakan menggunakan jenis penelitian survei dan desain kuantitatif. Kerlinger (2014:661) "Arah penelitian survei adalah untuk menganalisis karakteristik-karakteristik dari populasi dengan jumlah besar". Selain itu juga bertujuan untuk mencari kesamaan dari populasi dengan cara melihat perbandingannya terhadap standar yang telah ditentukan, dengan demikian penelitian ini akan mengukur bagaimana perbandingan sikap siswa terhadap mata pelajaran IPA SMP Sekabupaten Muaro Jambi.

\section{Sampel penelitian}

Teknik pengambilan sampel yang digunakan yaitu total sampling dan purposive sampling. Hal ini dilakukan peneliti karena ingin melihat sikap seluruh siswa kelas VII dan VIII di Kabupaten Muaro Jambi terhadap IPA dengan jumlah sampel untuk pengisian kuisoner sebagai teknik pengambilan total sampling sebanyak 2815 orang siswa terdiri dari 770 sampel di Kecamatan Sekernan, 337 sampel di Kecamatan Sungai Bahar, 458 sampel di Kecamatan Kumpeh Ulu, 272 sampel di Kecamatan Kumpeh, 563 sampel di Kecamatan Mestong, dan 415 sampel di Kecamatan Maro Sebo. Sedangkan teknik pengambilan data purposive sampling dengan dilakukannya wawancara sebanyak 36 sampel dari total keseluruhan siswa sebagai penguat data angket.

terhadap pembelajaran IPA. Skala yang digunakan pada instrumen angket sikap ini adalah skala likert lima poin yang terdiri dari (STS=sangat tidak setuju, TS=tidak setuju, $\mathrm{N}=$ netral, $\mathrm{S}=$ =setuju, $\mathrm{SS}=$ sangat setuju). Instrumen ini 
menggunakan 3 indikator yang diadopsi dari TOSRA milik Fraser (1981) yakni implikasi sosial dari IPA berjumlah 5 pernyataan, Karakteristik memperbanyak waktu belajar IPA berjumlah 8 pernyataan, dan Ketertarikan berkarir dibidan IPA berjumlah 10 pernyataan. Hasil dari 23 pernyataan dari 3 indikator sikap siswa terhadap mata pelajaran IPA terlihat pada tabel 1.1

Tabel 1.1 Pernyataan dan Indikator Sikap Terhadap mata pelajaran IPA

\begin{tabular}{|c|c|c|c|c|}
\hline \multirow{2}{*}{ Variabel } & \multirow{2}{*}{ Indikator } & \multicolumn{2}{|c|}{ Pernyataan } & \multirow{2}{*}{$\begin{array}{l}\text { Jumlah } \\
\text { Item }\end{array}$} \\
\hline & & Positif (+) & Negatif (-) & \\
\hline \multirow{3}{*}{$\begin{array}{c}\text { Sikap Siswa } \\
\text { terhadap mata } \\
\text { pelajaran IPA }\end{array}$} & $\begin{array}{l}\text { Implikasi sosial } \\
\text { dari IPA }\end{array}$ & 15,29 & $1,8,22$ & 5 \\
\hline & $\begin{array}{l}\text { Ketertarikan } \\
\text { memperbanyak } \\
\text { waktu belajar } \\
\text { IPA }\end{array}$ & $6,20,34,44$ & $13,27,39,48$ & 8 \\
\hline & $\begin{array}{l}\text { Ketertarikan } \\
\text { berkariri } \\
\text { dibidang IPA }\end{array}$ & $\begin{array}{c}14,28,40,49 \\
54\end{array}$ & $7,21,35,45,52$ & 10 \\
\hline
\end{tabular}

Prosedur penelitian ini dilakukan mulai dari menyebarkan kuesioner, kemudian analisis data angket sikap kemudian melanjutkan dengan mentranskrip seluruh data hasil yang telah didapatkan selama penelitian berlangsung.

\section{HASIL DAN PEMBAHASAN}

Implikasi Sosial Dari IPA

Hasil analisis data statistik yang diperoleh dari tiap kecamatan yang ada di Kabupaten Muaro Jambi mengenai sikap siswa terhadap mata pelajaran IPA yang ditinjau dari indikator implikasi sosial dari IPA dapat diukur melalui bagaimana sikap sosial siswa dalam mengikuti

pembelajaran di dalam kelas, persepsi siswa mengenai pembelajaran IPA,

\section{Analisis data}

Analisis data yang digunakan pada penelitian ini ada 2 yaitu jenis data statistik deskriptif untuk data kuantitatif yang berupa mean, modus, median, standar deviasi.

keaktifan, kreatif serta motivasi siswa terhadap mata pelajaran IPA juga dapat mengimplikasikan sikap sosial dari IPA. Seperti pada penelitian Chairunnisa (2017) dalam kegiatan pembelajaran peran guru sangat penting terutama dalam memberi motivasi siswa dalam belajar. Hal ini dapat dilihat berdasarkan penjabaran data statistik di bawah ini:

Tabel 1.2 Implikasi sosial dari IPA Kecamatan Sekernan

\begin{tabular}{|c|c|c|c|c|c|c|c|c|c|}
\hline Rentang & Sikap & Jumlah & $\%$ & Mean & Median & Modus & $\begin{array}{c}\text { Std. } \\
\text { deviasi }\end{array}$ & Min & Max \\
\hline $11 \mathrm{~s} / \mathrm{d} 13,8$ & $\begin{array}{c}\text { Sangat } \\
\text { Tidak Baik }\end{array}$ & 9 & $1 \%$ & \multirow{5}{*}{19,87} & \multirow{5}{*}{20} & \multirow{5}{*}{20} & \multirow{5}{*}{2,659} & \multirow{5}{*}{11} & \multirow{5}{*}{25} \\
\hline $\begin{array}{c}13,9 \mathrm{~s} / \mathrm{d} \\
16,6\end{array}$ & Tidak Baik & 71 & $9 \%$ & & & & & & \\
\hline $\begin{array}{c}16,7 \mathrm{~s} / \mathrm{d} \\
19,4\end{array}$ & Cukup Baik & 237 & $31 \%$ & & & & & & \\
\hline $\begin{array}{c}19,5 \mathrm{~s} / \mathrm{d} \\
22,2\end{array}$ & Baik & 325 & $42 \%$ & & & & & & \\
\hline $22,3 \mathrm{~s} / \mathrm{d} 25$ & Sangat Baik & 128 & $17 \%$ & & & & & & \\
\hline
\end{tabular}

Kecamatan Sekernan memiliki total keseluruhan siswa sebanyak 770 siswa, berdasarkan hasil data statistik tidak baik sebanyak $1 \% \quad$ (9 dari 770 siswa), tidak baik 9\% (71 dari 770 siswa), 
cukup baik 31\% (237 dari 770 siswa), baik 42\% (325 dari 770 siswa), sangat baik 17\% (128 dari 770 siswa). Sehingga siswa SMP Kecamatan Sekernan memiliki sikap implikasi sosial dari IPA dengan kategori dominan baik sebesar $42 \%$ dari total keseluruhan.

Tabel 1.3 Implikasi sosial dari IPA Kecamatan Sungai Bahar

\begin{tabular}{|c|c|c|c|c|c|c|c|c|c|}
\hline Rentang & Sikap & Jumlah & $\%$ & Mean & Median & Modus & Std.deviasi & Min & Max \\
\hline $12 \mathrm{~s} / \mathrm{d} 14,6$ & $\begin{array}{c}\text { Sangat } \\
\text { Tidak Baik }\end{array}$ & 6 & $2 \%$ & \multirow{5}{*}{20,31} & \multirow{5}{*}{20} & \multirow{5}{*}{22} & \multirow{5}{*}{2,469} & \multirow{5}{*}{12} & \multirow{5}{*}{25} \\
\hline 14,7 s/d 17,2 & Tidak Baik & 32 & $9 \%$ & & & & & & \\
\hline $17,3 \mathrm{~s} / \mathrm{d} 19,8$ & Cukup Baik & 81 & $24 \%$ & & & & & & \\
\hline $19,9 \mathrm{~s} / \mathrm{d} 22,4$ & Baik & 158 & $47 \%$ & & & & & & \\
\hline $22,5 \mathrm{~s} / \mathrm{d} 25$ & Sangat Baik & 60 & $18 \%$ & & & & & & \\
\hline
\end{tabular}

Kecamatan Sungai Bahar memiliki total keseluruhan siswa sebanyak 337 siswa, berdasarkan hasil data statistik dapat dilihat siswa memiliki sikap sangat tidak baik sebanyak 2\% (6 dari 337 siswa), tidak baik 9\% (32 dari 337 siswa), cukup baik 22\% (81 dari 337 siswa), baik
47\% (158 dari 337 siswa), sangat baik 18\% (60 dari 337 siswa. sehingga siswa SMP Kecamatan Sungai Bahar memiliki sikap implikasi sosial dari IPA dengan kategori dominan baik sebesar $47 \%$ dari total keseluruhan.

Tabel 1.4 Implikasi sosial dari IPA Kecamatan Kumpeh Ulu

\begin{tabular}{|c|c|c|c|c|c|c|c|c|c|}
\hline Rentang & Sikap & Jumlah & $\%$ & Mean & Median & Modus & Std.deviasi & Min & Max \\
\hline $10 \mathrm{~s} / \mathrm{d} 13$ & $\begin{array}{c}\text { Sangat } \\
\text { Tidak Baik }\end{array}$ & 9 & $2 \%$ & \multirow{5}{*}{19,76} & \multirow{5}{*}{20} & \multirow{5}{*}{20} & \multirow{5}{*}{2,884} & \multirow{5}{*}{10} & \multirow{5}{*}{25} \\
\hline $14 \mathrm{~s} / \mathrm{d} 16$ & Tidak Baik & 52 & $11 \%$ & & & & & & \\
\hline 17 s/d 19 & Cukup Baik & 135 & $29 \%$ & & & & & & \\
\hline $20 \mathrm{~s} / \mathrm{d} 22$ & Baik & 190 & $41 \%$ & & & & & & \\
\hline $23 \mathrm{~s} / \mathrm{d} 25$ & Sangat Baik & 72 & $16 \%$ & & & & & & \\
\hline
\end{tabular}

Kecamatan Kumpeh Ulu memiliki total keseluruhan siswa sebanyak 458 siswa, berdasarkan hasil data statistik dapat dilihat siswa memiliki sikap sangat tidak baik sebanyak 2\% (9 dari 458 siswa), tidak baik $11 \%$ (52 dari 458 siswa), cukup baik 29\% (135 dari 458 siswa), baik 41\% (190 dari 458 siswa), sangat baik 16\% (72 dari 458 siswa). sehingga siswa SMP Kecamatan Kumpeh Ulu memiliki sikap implikasi sosial dari IPA dengan kategori dominan baik sebesar $41 \%$ dari total keseluruhan.

Tabel 1.5 Implikasi sosial dari IPA Kecamatan Kumpeh

\begin{tabular}{|c|c|c|c|c|c|c|c|c|c|}
\hline Rentang & Sikap & Jumlah & $\%$ & Mean & Median & Modus & Std.deviasi & Min & Max \\
\hline $11 \mathrm{~s} / \mathrm{d} 13,8$ & $\begin{array}{c}\text { Sangat } \\
\text { Tidak Baik }\end{array}$ & 6 & $2 \%$ & \multirow{5}{*}{19,6} & \multirow{5}{*}{20} & \multirow{5}{*}{20} & \multirow{5}{*}{2,683} & \multirow{5}{*}{11} & \multirow{5}{*}{25} \\
\hline 13,9 s/d 16,6 & Tidak Baik & 32 & $12 \%$ & & & & & & \\
\hline 16,7 s/d 19,4 & Cukup Baik & 82 & $30 \%$ & & & & & & \\
\hline $19,5 \mathrm{~s} / \mathrm{d} 22,2$ & Baik & 117 & $43 \%$ & & & & & & \\
\hline $22,3 \mathrm{~s} / \mathrm{d} 25$ & Sangat Baik & 35 & $13 \%$ & & & & & & \\
\hline
\end{tabular}

Kecamatan Kumpeh memiliki total keseluruhan siswa sebanyak 272 siswa, berdasarkan hasil data statistik dapat dilihat siswa memiliki sikap sangat tidak baik sebanyak 2\% (6 dari 272 siswa), tidak baik 12\% (32 dari 272 siswa), cukup 
baik 30\% (82 dari 272 siswa), baik 13\% (117 dari 272 siswa), sangat baik 13\% (35 dari 272 siswa). sehingga siswa SMP Kecamatan Kumpeh memiliki sikap implikasi sosial dari IPA dengan kategori dominan baik sebesar $43 \%$ dari total keseluruhan.

Tabel 1.6 Implikasi sosial dari IPA Kecamatan Mestong

\begin{tabular}{|c|c|c|c|c|c|c|c|c|c|}
\hline Rentang & Sikap & Jumlah & $\%$ & Mean & Median & Modus & Std.deviasi & Min & Max \\
\hline $11 \mathrm{~s} / \mathrm{d} 13,8$ & $\begin{array}{c}\text { Sangat } \\
\text { Tidak Baik }\end{array}$ & 7 & $1 \%$ & \multirow{5}{*}{19,5} & \multirow{5}{*}{19} & \multirow{5}{*}{19} & \multirow{5}{*}{2,614} & \multirow{5}{*}{11} & \multirow{5}{*}{25} \\
\hline 13,9 s/d 16,6 & Tidak Baik & 69 & $12 \%$ & & & & & & \\
\hline $16,7 \mathrm{~s} / \mathrm{d} 19,4$ & Cukup Baik & 206 & $37 \%$ & & & & & & \\
\hline $19,5 \mathrm{~s} / \mathrm{d} 22,2$ & Baik & 205 & $36 \%$ & & & & & & \\
\hline $22,3 \mathrm{~s} / \mathrm{d} 25$ & Sangat Baik & 76 & $13 \%$ & & & & & & \\
\hline
\end{tabular}

Kecamatan Mestong memiliki total keseluruhan siswa sebanyak 563 siswa, berdasarkan hasil data statistik dapat dilihat siswa memiliki sikap sangat tidak baik sebanyak $1 \%$ (7 dari 563 siswa), tidak baik 12\% (69 dari 563 siswa), cukup baik 37\% (206 dari 563 siswa), baik 36\% (205 dari 563 siswa), sangat baik 13\% (76 dari 563 siswa). sehingga siswa SMP Kecamatan Mestong memiliki sikap implikasi sosial dari IPA dengan kategori dominan cukup baik sebesar $37 \%$ dari total keseluruhan

Tabel 1.7 Implikasi sosial dari IPA Kecamatan Maro Sebo

\begin{tabular}{|c|c|c|c|c|c|c|c|c|c|}
\hline Rentang & Sikap & Jumlah & $\%$ & Mean & Median & Modus & Std.deviasi & Min & $\operatorname{Max}$ \\
\hline $10 \mathrm{~s} / \mathrm{d} 13$ & $\begin{array}{c}\text { Sangat } \\
\text { Tidak Baik }\end{array}$ & 20 & $5 \%$ & \multirow{5}{*}{19,18} & \multirow{5}{*}{19} & \multirow{5}{*}{19} & \multirow{5}{*}{2,989} & \multirow{5}{*}{10} & \multirow{5}{*}{25} \\
\hline $14 \mathrm{~s} / \mathrm{d} 16$ & Tidak Baik & 58 & $14 \%$ & & & & & & \\
\hline 17 s/d 19 & Cukup Baik & 130 & $31 \%$ & & & & & & \\
\hline $20 \mathrm{~s} / \mathrm{d} 22$ & Baik & 159 & $38 \%$ & & & & & & \\
\hline $23 \mathrm{~s} / \mathrm{d} 25$ & Sangat Baik & 48 & $12 \%$ & & & & & & \\
\hline
\end{tabular}

Kecamatan Maro Sebo memiliki total keseluruhan siswa sebanyak 415 siswa, berdasarkan hasil data statistik dapat dilihat siswa memiliki sikap sangat tidak baik sebanyak 5\% (20 dari 415 siswa), tidak baik 14\% (58 dari415 siswa), cukup baik 31\% (130 dari 415 siswa), baik 38\% (159 dari 415 siswa), sangat baik 12\% (48 dari 415 siswa). sehingga siswa SMP Kecamatan Maro Sebo memiliki sikap implikasi sosial dari IPA dengan kategori dominan baik sebesar 38 $\%$ dari total keseluruhan.

Berdasarkan data statistik yang dipaparkan menunjukkan ada 1 Kecamatan yang memiliki kategori cukup baik yaitu Kecamatan Kecamatan Mestong 37\% (206 dari 568 siswa), sedangkan yang menjawab dengan kategori baik ada 5 kecamatan yaitu Kecamatan Skernan baik 42\% (325 dari
770 siswa), Sungai Bahar 47\% (158 dari 737 siswa), Kecamatan Kumpeh Ulu 41\% (190 dari 458 siswa), Kecamatan Kumpeh 34\% (117 dari 272 siswa), dan Kecamatan Maro Sebo 38\% (159 dari 415 siswa). Hal ini menunjukkan dari 6 kecamatan ada 5 kecamatan yang berkategori baik, artinya pada indikator implikasi sosial dari IPA di Kabupaten Muaro Jambi memiliki sikap yang dominan pada kategori baik.

\section{Ketertarikan Memperbanyak Waktu Belajar IPA}

Hasil analisis data statistik yang diperoleh dari tiap kecamatan yang ada di Kabupaten Muaro Jambi mengenai sikap siswa terhadap mata pelajaran IPA yang ditinjau dari indikator ketertarikan memperbanyak waktu belajar IPA, hal ini juga berkaitan erat dengan implikasi sosial dari IPA yang dimiliki pada individu siswa. Sikap ketertarikan menambah 
waktu ini dapat dilihat bagaimana ketertarikan siswa dalam dunia sains dengan sikapnya yang menyukai membaca mengenai sains, menghabiskan waktu untuk mencari informasi mengenai
IPA, bereksperimen hingga berkunjung ke laboratorium. Hal ini dapat dilihat berdasarkan penjabaran data statistik di bawah ini:

Tabel 1.8 Ketertarikan menambah waktu belajar IPA Kecamatan Sekernan

\begin{tabular}{|c|c|c|c|c|c|c|c|c|c|}
\hline Rentang & Sikap & Jumlah & $\%$ & Mean & Median & Modus & Std.deviasi & Min & Max \\
\hline 13 s/d 18,2 & $\begin{array}{c}\text { Sangat } \\
\text { Tidak Baik }\end{array}$ & 12 & $2 \%$ & \multirow{5}{*}{28,2} & \multirow{5}{*}{28} & \multirow{5}{*}{31} & \multirow{5}{*}{4,24} & \multirow{5}{*}{13} & \multirow{5}{*}{39} \\
\hline $18,3 \mathrm{~s} / \mathrm{d} 23,4$ & Tidak Baik & 90 & $12 \%$ & & & & & & \\
\hline 23,5 s/d 28,6 & Cukup Baik & 297 & $39 \%$ & & & & & & \\
\hline 28,7 s/d 33,8 & Baik & 296 & $38 \%$ & & & & & & \\
\hline 33,9 s/d 39 & Sangat Baik & 75 & $10 \%$ & & & & & & \\
\hline
\end{tabular}

Kecamatan Sekernan memiliki total keseluruhan siswa sebanyak 563 siswa, berdasarkan hasil data statistik dapat dilihat siswa SMP Kecamatan Sekernan memiliki sikap ketertarikan menambah waktu belajar IPA dengan kategori dominan cukup baik sebesar 39\% (297 dari 567 siswa) terhitung dari total keseluruhan siswa.

Tabel 1.9 ketertarikan menambah waktu belajar IPA Kecamatan Sungai Bahar

\begin{tabular}{|c|c|c|c|c|c|c|c|c|c|}
\hline Rentang & Sikap & Jumlah & $\%$ & Mean & Median & Modus & Std.deviasi & Min & Max \\
\hline 14 s/d 19,2 & $\begin{array}{c}\text { Sangat } \\
\text { Tidak Baik }\end{array}$ & 8 & $2 \%$ & \multirow{5}{*}{27,93} & \multirow{5}{*}{28} & \multirow{5}{*}{27} & \multirow{5}{*}{4,351} & \multirow{5}{*}{14} & \multirow{5}{*}{40} \\
\hline 19,3 s/d 24,2 & Tidak Baik & 60 & $18 \%$ & & & & & & \\
\hline 24,3 s/d 29,6 & Cukup Baik & 152 & $45 \%$ & & & & & & \\
\hline 29,7 s/d 34,8 & Baik & 95 & $28 \%$ & & & & & & \\
\hline $34,9 \mathrm{~s} / \mathrm{d} 40$ & Sangat Baik & 22 & $7 \%$ & & & & & & \\
\hline
\end{tabular}

Kecamatan Sungai Bahar memiliki total keseluruhan siswa sebanyak 337 siswa, berdasarkan hasil data statistik dapat dilihat siswa SMP Kecamatan Sungai Bahar memiliki sikap ketertarikan menambah waktu belajar IPA dengan kategori dominan cukup baik sebesar $45 \%$ (152 dari 337 siswa) terhitung dari total keseluruhan siswa.

Tabel 1.10 ketertarikan menambah waktu belajar IPA Kecamatan Kumpeh Ulu

\begin{tabular}{|c|c|c|c|c|c|c|c|c|c|}
\hline Rentang & Sikap & Jumlah & $\%$ & Mean & Median & Modus & Std.deviasi & Min & Max \\
\hline $15 \mathrm{~s} / \mathrm{d} 20$ & $\begin{array}{c}\text { Sangat } \\
\text { Tidak Baik }\end{array}$ & 28 & $6 \%$ & \multirow{5}{*}{28,19} & \multirow{5}{*}{28} & \multirow{5}{*}{27} & \multirow{5}{*}{4,464} & \multirow{5}{*}{15} & \multirow{5}{*}{40} \\
\hline $21 \mathrm{~s} / \mathrm{d} 25$ & Tidak Baik & 81 & $18 \%$ & & & & & & \\
\hline $26 \mathrm{~s} / \mathrm{d} 30$ & Cukup Baik & 219 & $48 \%$ & & & & & & \\
\hline $31 \mathrm{~s} / \mathrm{d} 35$ & Baik & 103 & $22 \%$ & & & & & & \\
\hline $36 \mathrm{~s} / \mathrm{d} 40$ & Sangat Baik & 27 & $6 \%$ & & & & & & \\
\hline
\end{tabular}

Kecamatan Kumpeh Ulu memiliki total keseluruhan siswa sebanyak 458 siswa, berdasarkan hasil data statistik dapat dilihat siswa SMP Kecamatan Kumpeh memiliki sikap ketertarikan menambah waktu belajar IPA dengan kategori dominan cukup baik sebesar $48 \%$ (219 dari 458 siswa) terhitung dari total keseluruhan siswa.

Tabel 1.11ketertarikan menambah waktu belajar IPA Kecamatan Kumpeh

\begin{tabular}{llllllllll}
\hline Rentang & Sikap & Jumlah & $\%$ & Mean & Median & Modus & Std.deviasi & Min & Max \\
\hline
\end{tabular}




\begin{tabular}{|c|c|c|c|c|c|c|c|c|c|}
\hline $18 \mathrm{~s} / \mathrm{d} 22,4$ & $\begin{array}{c}\text { Sangat } \\
\text { Tidak Baik }\end{array}$ & 14 & $5 \%$ & \multirow{5}{*}{29,14} & \multirow{5}{*}{29} & \multirow{5}{*}{29} & \multirow{5}{*}{4,414} & \multirow{5}{*}{18} & \multirow{5}{*}{40} \\
\hline $22,5 \mathrm{~s} / \mathrm{d} 26,8$ & Tidak Baik & 67 & $25 \%$ & & & & & & \\
\hline 26,9 s/d 31,2 & Cukup Baik & 107 & $39 \%$ & & & & & & \\
\hline $31,3 \mathrm{~s} / \mathrm{d} 35,6$ & Baik & 67 & $25 \%$ & & & & & & \\
\hline $35,7 \mathrm{~s} / \mathrm{d} 40$ & Sangat Baik & 17 & $6 \%$ & & & & & & \\
\hline
\end{tabular}

Kecamatan Kumpeh memiliki total keseluruhan siswa sebanyak 272 siswa, berdasarkan hasil data statistik dapat dilihat siswa SMP Kecamatan Kumpeh memiliki sikap ketertarikan menambah waktu belajar IPA dengan kategori dominan cukup baik sebesar 39\% (107 dari 272 siswa) terhitung dari total keseluruhan siswa.

Tabel 1.12 Ketertarikan menambah waktu belajar IPA Kecamatan Mestong

\begin{tabular}{|c|c|c|c|c|c|c|c|c|c|}
\hline Rentang & Sikap & Jumlah & $\%$ & Mean & Median & Modus & Std.deviasi & Min & Max \\
\hline $11 \mathrm{~s} / \mathrm{d} 16,8$ & $\begin{array}{c}\text { Sangat } \\
\text { Tidak Baik }\end{array}$ & 10 & $2 \%$ & \multirow{5}{*}{28,06} & \multirow{5}{*}{28} & \multirow{5}{*}{26} & \multirow{5}{*}{5,108} & \multirow{5}{*}{11} & \multirow{5}{*}{40} \\
\hline $16,9 \mathrm{~s} / \mathrm{d} 22,6$ & Tidak Baik & 65 & $12 \%$ & & & & & & \\
\hline $22,7 \mathrm{~s} / \mathrm{d} 28,4$ & Cukup Baik & 223 & $40 \%$ & & & & & & \\
\hline $28,5 \mathrm{~s} / \mathrm{d} 34,2$ & Baik & 206 & $37 \%$ & & & & & & \\
\hline $34,3 \mathrm{~s} / \mathrm{d} 40$ & Sangat Baik & 59 & $10 \%$ & & & & & & \\
\hline
\end{tabular}

Kecamatan Mestong memiliki total keseluruhan siswa sebanyak 563 siswa, berdasarkan hasil data statistik dapat dilihat siswa SMP Kecamatan Mestong memiliki sikap ketertarikan menambah waktu belajar IPA dengan kategori dominan cukup baik sebesar $40 \%$ (223 dari 563 siswa) terhitung dari total keseluruhan siswa.

Tabel 1.2 ketertarikan menambah waktu belajar IPA Kecamatan Maro Sebo

\begin{tabular}{|c|c|c|c|c|c|c|c|c|c|}
\hline Rentang & Sikap & Jumlah & $\%$ & Mean & Median & Modus & Std.deviasi & Min & Max \\
\hline 14 s/d 18,8 & $\begin{array}{c}\text { Sangat } \\
\text { Tidak Baik }\end{array}$ & 7 & $2 \%$ & \multirow{5}{*}{26,58} & \multirow{5}{*}{26} & \multirow{5}{*}{26} & \multirow{5}{*}{4,108} & \multirow{5}{*}{14} & \multirow{5}{*}{38} \\
\hline 18,9 s/d 23,6 & Tidak Baik & 88 & $21 \%$ & & & & & & \\
\hline 23,7 s/d 28,4 & Cukup Baik & 189 & $46 \%$ & & & & & & \\
\hline 28,5 s/d 33,2 & Baik & 112 & $27 \%$ & & & & & & \\
\hline 33,3 s/d 38 & Sangat Baik & 19 & $5 \%$ & & & & & & \\
\hline
\end{tabular}

Kecamatan Maro Sebo memiliki total keseluruhan siswa sebanyak 415 siswa, berdasarkan hasil data statistik dapat dilihat siswa SMP Kecamatan Maro Sebo memiliki sikap ketertarikan menambah waktu belajar IPA dengan kategori dominan cukup baik sebesar $46 \%$ (189 dari 415 siswa) terhitung dari total keseluruhan siswa

Berdasarkan data statistik yang dipaparkan menunjukkan hasil dari 6 Kecamatan yang ada di Kabupaten Muaro Jambi memiliki kategori cukup baik terlihat pada Kecamatan Sekernan 39\% (297 dari 770 siswa), Kecamatan Sungai
Bahar 45\% ( 152 dari 337 siswa), Kecamatan Kumpeh Ulu 48\% (219 dari 458 siswa), Kecamatan Kumpeh 39\% (107 dari 272 siswa), Kecamatan Mestong 40\% (223 dari 563 siswa), dan Kecamatan Maro Sebo 46\% (189 dari 415 siswa). Hal ini menunjukkan sikap siswa pada kategori ketertarikan menambah waktu belajar IPA pada siswa SMP di Kabupaten Muaro Jambi masih tergolong rendah dengan sikap dominan adalah cukup baik. Ketertarikan Berkarir Dibidang IPA

Implikasi sosial dari IPA, Ketertarikan menambah waktu belajar IPA, memiliki keterkaitan pada 
ketertarikan siswa untuk berkarir di bidang IPA. Analisis data statistik kuesioner sikap siswa terhadap IPA pada indikator ketertarikan berkarir dibidang IPA dapat di ukur dengan melihat seberapa besar keinginan siswa tersebut berkarir dalam bidang IPA, baik itu menjadi seorang ilmuan ataupun di laboratorium. Hal ini dapat dilihat berdasarkan penjabaran data statistik di bawah ini:

Tabel 1.13 Ketertarikan berkarir dibidang IPA Kecamatan Sekernan

\begin{tabular}{|c|c|c|c|c|c|c|c|c|c|}
\hline Rentang & Sikap & Jumlah & $\%$ & Mean & Median & Modus & Std.deviasi & Min & $\operatorname{Max}$ \\
\hline 16 s/d 22,4 & $\begin{array}{c}\text { Sangat } \\
\text { Tidak Baik }\end{array}$ & 3 & $0 \%$ & \multirow{5}{*}{35,44} & \multirow{5}{*}{35} & \multirow{5}{*}{36} & \multirow{5}{*}{5,45} & \multirow{5}{*}{16} & \multirow{5}{*}{48} \\
\hline 22,5 s/d 28,8 & Tidak Baik & 65 & $8 \%$ & & & & & & \\
\hline 28,9 s/d 35,2 & Cukup Baik & 336 & $44 \%$ & & & & & & \\
\hline $35,3 \mathrm{~s} / \mathrm{d} 41,6$ & Baik & 251 & $33 \%$ & & & & & & \\
\hline $41,7 \mathrm{~s} / \mathrm{d} 48$ & Sangat Baik & 115 & $15 \%$ & & & & & & \\
\hline
\end{tabular}

Kecamatan Skernan memiliki total keseluruhan siswa sebanyak 770 siswa, berdasarkan hasil data statistik dapat dilihat siswa SMP Kecamatan Skernan memiliki sikap ketertarikan berkarir dibidang IPA dengan kategori dominan cukup baik sebesar 44\% (336 dari 770 siswa) terhitung dari total keseluruhan siswa.

Tabel 1.14 ketertarikan berkarir dibidang IPA Kecamatan Sungai Bahar

\begin{tabular}{|c|c|c|c|c|c|c|c|c|c|}
\hline Rentang & Sikap & Jumlah & $\%$ & Mean & Median & Modus & Std.deviasi & Min & $\operatorname{Max}$ \\
\hline $17 \mathrm{~s} / \mathrm{d} 23,6$ & $\begin{array}{c}\text { Sangat } \\
\text { Tidak Baik }\end{array}$ & 6 & $2 \%$ & \multirow{5}{*}{35,2} & \multirow{5}{*}{35} & \multirow{5}{*}{33} & \multirow{5}{*}{5,565} & \multirow{5}{*}{17} & \multirow{5}{*}{50} \\
\hline 23,7 s/d 30,2 & Tidak Baik & 65 & $19 \%$ & & & & & & \\
\hline 30,3 s/d 36,8 & Cukup Baik & 148 & $44 \%$ & & & & & & \\
\hline 36,9 s/d 43,3 & Baik & 88 & $26 \%$ & & & & & & \\
\hline $43,5 \mathrm{~s} / \mathrm{d} 50$ & Sangat Baik & 30 & $9 \%$ & & & & & & \\
\hline
\end{tabular}

Kecamatan Sungai Bahar memiliki total keseluruhan siswa sebanyak 770 siswa, berdasarkan hasil data statistik dapat dilihat siswa SMP Kecamatan Sungai Bahar memiliki sikap ketertarikan berkarir dibidang IPA dengan kategori dominan cukup baik sebesar 44\% (148 dari 337 siswa) terhitung dari total keseluruhan siswa.

Tabel 1.15 ketertarikan berkarir dibidang IPA Kecamatan Kumpeh Ulu

\begin{tabular}{|c|c|c|c|c|c|c|c|c|c|}
\hline Rentang & Sikap & Jumlah & $\%$ & Mean & Median & Modus & Std.deviasi & Min & $\operatorname{Max}$ \\
\hline $12 \mathrm{~s} / \mathrm{d} 19,6$ & $\begin{array}{c}\text { Sangat } \\
\text { Tidak Baik }\end{array}$ & 6 & $1 \%$ & \multirow{5}{*}{34,72} & \multirow{5}{*}{35} & \multirow{5}{*}{35} & \multirow{5}{*}{5,931} & \multirow{5}{*}{12} & \multirow{5}{*}{50} \\
\hline $19,7 \mathrm{~s} / \mathrm{d} 27,2$ & Tidak Baik & 40 & $9 \%$ & & & & & & \\
\hline $27,3 \mathrm{~s} / \mathrm{d} 34,8$ & Cukup Baik & 179 & $39 \%$ & & & & & & \\
\hline 34,9 s/d 42,4 & Baik & 191 & $42 \%$ & & & & & & \\
\hline $42,5 \mathrm{~s} / \mathrm{d} 50$ & Sangat Baik & 42 & $9 \%$ & & & & & & \\
\hline
\end{tabular}

Kecamatan Kumpeh Ulu memiliki total keseluruhan siswa sebanyak 458 siswa, berdasarkan hasil data statistik dapat dilihat siswa SMP Kecamatan Kumpeh Ulu memiliki sikap ketertarikan berkarir dibidang IPA dengan kategori dominan cukup baik sebesar 39\% (179 dari 458 siswa) terhitung dari total keseluruhan siswa. 
Tabel 1.16 ketertarikan berkarir dibidang IPA Kecamatan Kumpeh

\begin{tabular}{|c|c|c|c|c|c|c|c|c|c|}
\hline Rentang & Sikap & Jumlah & $\%$ & Mean & Median & Modus & Std.deviasi & Min & Max \\
\hline $23 \mathrm{~s} / \mathrm{d} 28,4$ & $\begin{array}{c}\text { Sangat } \\
\text { Tidak Baik } \\
\end{array}$ & 23 & $8 \%$ & \multirow{5}{*}{36,18} & \multirow{5}{*}{36} & \multirow{5}{*}{31} & \multirow{5}{*}{6,052} & \multirow{5}{*}{23} & \multirow{5}{*}{50} \\
\hline $28,5 \mathrm{~s} / \mathrm{d} 33,8$ & Tidak Baik & 78 & $29 \%$ & & & & & & \\
\hline 33,9 s/d 39,2 & Cukup Baik & 91 & $33 \%$ & & & & & & \\
\hline $39,3 \mathrm{~s} / \mathrm{d} 44,6$ & Baik & 51 & $19 \%$ & & & & & & \\
\hline $44,7 \mathrm{~s} / \mathrm{d} 50$ & Sangat Baik & 29 & $11 \%$ & & & & & & \\
\hline
\end{tabular}

Kecamatan Kumpeh memiliki total keseluruhan siswa sebanyak 272 siswa, berdasarkan hasil data statistik dapat dilihat siswa SMP Kecamatan Kumpeh memiliki sikap ketertarikan berkarir dibidang IPA dengan kategori dominan cukup baik sebesar 33\% (91 dari 272 siswa) terhitung dari total keseluruhan siswa.

Tabel 1.17 ketertarikan berkarir dibidang IPA Kecamatan Mestong

\begin{tabular}{|c|c|c|c|c|c|c|c|c|c|}
\hline Rentang & Sikap & Jumlah & $\%$ & Mean & Median & Modus & Std.deviasi & Min & Max \\
\hline $13 \mathrm{~s} / \mathrm{d} 20,4$ & $\begin{array}{c}\text { Sangat } \\
\text { Tidak Baik }\end{array}$ & 4 & $1 \%$ & \multirow{5}{*}{35,25} & \multirow{5}{*}{35} & \multirow{5}{*}{36} & \multirow{5}{*}{6,268} & \multirow{5}{*}{13} & \multirow{5}{*}{50} \\
\hline 20,5 s/d 27,8 & Tidak Baik & 50 & $9 \%$ & & & & & & \\
\hline 27,9 s/d 35,2 & Cukup Baik & 232 & $41 \%$ & & & & & & \\
\hline $35,3 \mathrm{~s} / \mathrm{d} 42,6$ & Baik & 199 & $35 \%$ & & & & & & \\
\hline $42,7 \mathrm{~s} / \mathrm{d} 50$ & Sangat Baik & 78 & $14 \%$ & & & & & & \\
\hline
\end{tabular}

Kecamatan Mestong memiliki total keseluruhan siswa sebanyak 563 siswa, berdasarkan hasil data statistik dapat dilihat siswa SMP Kecamatan Mestong memiliki sikap ketertarikan berkarir dibidang IPA dengan kategori dominan baik sebesar 35\% (199 dari 363 siswa) terhitung dari total keseluruhan siswa.

Tabel 1.17 ketertarikan berkarir dibidang IPA Kecamatan Maro Sebo

\begin{tabular}{|c|c|c|c|c|c|c|c|c|c|}
\hline Rentang & Sikap & Jumlah & $\%$ & Mean & Median & Modus & Std.deviasi & Min & Max \\
\hline 19 s/d 24,8 & $\begin{array}{c}\text { Sangat } \\
\text { Tidak Baik }\end{array}$ & 14 & $3 \%$ & \multirow{5}{*}{38,89} & \multirow{5}{*}{34} & \multirow{5}{*}{36} & \multirow{5}{*}{5,244} & \multirow{5}{*}{19} & \multirow{5}{*}{48} \\
\hline 24,9 s/d 30,6 & Tidak Baik & 100 & $24 \%$ & & & & & & \\
\hline 30,7 s/d 36,4 & Cukup Baik & 180 & $43 \%$ & & & & & & \\
\hline $36,5 \mathrm{~s} / \mathrm{d} 42,3$ & Baik & 101 & $24 \%$ & & & & & & \\
\hline $42,3 \mathrm{~s} / \mathrm{d} 48$ & Sangat Baik & 20 & $5 \%$ & & & & & & \\
\hline
\end{tabular}

Kecamatan Maro Sebo memiliki total keseluruhan siswa sebanyak 415 siswa, berdasarkan hasil data statistik dapat dilihat siswa SMP Kecamatan Maro Sebo memiliki sikap ketertarikan berkarir dibidang IPA dengan kategori dominan cukup baik sebesar 43\% (180 dari 415 siswa) terhitung dari total keseluruhan siswa.
Berdasarkan tabel data statistik di atas menunjukkan bahwa hasil penelitian ini menggambarkan ada 1 Kecamatan yang memiliki kategori baik yaitu, Kecamatan Mestong 35\% (199 dari 568 siswa), selanjutnya ada 5 Kecamatan yang memiliki kategori cukup baik yaitu Kecamatan Sekernan 44\% (336 dari 770 siswa), Kecamatan Sungai Bahar 44\% (148 dari 337 siswa), Kecamatan Kumpeh Ulu 39\% (179 dari 458 siswa), Kecamatan 
Kumpeh 33\% (91 dari 272 siswa), dan Kecamatan Maro Sebo 43\% (180 dari 415 siswa). Hal ini menunjukkan siswa lebih dominan berkategori cukup baik sehingga tidak banyak siswa yang memiliki sikap baik dan positif terhadap pembelajaran IPA dengan menunjukkan ketertarikan berkarir dalam bidang IPA

Kendala

Berdasarkan data hasil dari tiap indikator tersebut terdapat beberapa kendala yang ada pada masing-masing indikator dengan jumlah total sampel SMP Se-Kabupaten Muaro Jambi yang dihitung berdasarkan Kecamatan yaitu sebanyak 770 siswa sampel di kecamatan Skernan, 337 siswa Kecamatan Sungai Bahar, 458 siswa Kecamatan Kumpeh Ulu, 272 siswa Kecamatan Kumpeh, 563 siswa Kecamatan Mestong, dan 415 siswa Kecamatan Maro Sebo. Adapun kendala tersebut dapat dipersentasekan berdasarkan tabel di bawah ini :

Tabel 1.18 Kendala sikap siswa SMP Se-Kabupaten Muaro Jambi pada indikator implikasi sosial dari IPA

\begin{tabular}{|c|c|c|c|c|}
\hline \multirow{3}{*}{ Kecamatan } & \multicolumn{2}{|c|}{ Indikator dan jawaban responden } & \multirow{3}{*}{ Jumlah } & \multirow{3}{*}{ Persentase } \\
\hline & \multicolumn{2}{|c|}{ Implikasi sosial dari IPA } & & \\
\hline & Sangat tidak baik & Tidak baik & & \\
\hline Sekernan & 9 & 71 & 80 & $10 \%$ \\
\hline Sungai Bahar & 6 & 32 & 38 & $11 \%$ \\
\hline Kumpeh Ulu & 9 & 52 & 61 & $13 \%$ \\
\hline Kumpeh & 6 & 32 & 38 & $14 \%$ \\
\hline Mestong & 7 & 69 & 76 & $13 \%$ \\
\hline Maro Sebo & 20 & 58 & 78 & $19 \%$ \\
\hline
\end{tabular}

Data hasil perhitungan statistik di atas menunjukkan adanya kendala pada indikator implikasi sosial dari IPA. Sikap siswa SMP di Kabupaten Muaro Jambi yang di tinjau per kecamatan menunjukkan Kecamatan Maro Sebo memiliki persentase tertinggi 19\% (18 dari 415 siswa).

Tabel 1.18 Kendala sikap siswa SMP Se-Kabupaten Muaro Jambi pada indikator ketertarikan memperbanyak waktu belajar IPA

\begin{tabular}{|c|c|c|c|c|}
\hline \multirow{3}{*}{ Kecamatan } & Indikator da & responden & \multirow{3}{*}{ Jumlah } & \multirow{3}{*}{ Persentase } \\
\hline & \multicolumn{2}{|c|}{ Ketertarikan menambah waktu belajar IPA } & & \\
\hline & Sangat tidak baik & Tidak baik & & \\
\hline Sekernan & 12 & 90 & 102 & $13 \%$ \\
\hline Sungai Bahar & 8 & 60 & 68 & $20 \%$ \\
\hline Kumpeh Ulu & 28 & 81 & 109 & $24 \%$ \\
\hline Kumpeh & 14 & 67 & 81 & $30 \%$ \\
\hline Mestong & 10 & 65 & 75 & $13 \%$ \\
\hline Maro Sebo & 7 & 88 & 95 & $23 \%$ \\
\hline
\end{tabular}

Data hasil perhitungan statistik di atas menunjukkan adanya kendala pada indikator ketertarikan menambah waktu belajar IPA. Sikap siswa SMP di Kabupaten Muaro Jambi yang di tinjau per kecamatan menunjukkan Kecamatan Kumpeh memiliki persentase tertinggi 30\% (81 dari 272 siswa). 
Tabel 1.18 Kendala sikap siswa SMP Se-Kabupaten Muaro Jambi pada indikator ketertarikan berkarir dibidang IPA

\begin{tabular}{|c|c|c|c|c|}
\hline \multirow{3}{*}{ Kecamatan } & \multicolumn{2}{|c|}{ Indikator dan jawaban responden } & \multirow{3}{*}{ Jumlah } & \multirow{3}{*}{ Persentase } \\
\hline & \multicolumn{2}{|c|}{ Ketertarikan berkarir dibidang IPA } & & \\
\hline & Sangat tidak baik & Tidak baik & & \\
\hline Sekernan & 3 & 65 & 68 & $9 \%$ \\
\hline Sungai Bahar & 6 & 65 & 71 & $21 \%$ \\
\hline Kumpeh Ulu & 6 & 40 & 46 & $10 \%$ \\
\hline Kumpeh & 20 & 78 & 98 & $36 \%$ \\
\hline Mestong & 4 & 50 & 54 & $10 \%$ \\
\hline Maro Sebo & 14 & 100 & 114 & $27 \%$ \\
\hline
\end{tabular}

Data hasil perhitungan statistik di atas menunjukkan adanya kendala pada indikator ketertarikan berkarir di bidang IPA. Sikap siswa SMP di Kabupaten Muaro Jambi yang di tinjau per kecamatan menunjukkan Kecamatan Kumpeh memiliki persentase tertinggi $36 \%$ (98

\section{PENUTUP}

\section{Kesimpulan}

Berdasarkan hasil analisis yang didapatkan, sikap siswa dalam tiap indikator per-kecamatannya memiliki kategori yang berbeda-beda, hal ini disebabkan oleh banyak faktor terutama dari guru pengampu bidang studi yang ada di sekolah, bagaimana cara guru dalam menanamkan konsep kepada siswa agar tidak memiliki anggapan bahwa IPA adalah pelajaran yang sulit. Selain itu siswa yang memiliki implikasi sosial dari IPA yang baik belum tentu memiliki keter-tarikan dalam menambah waktu belajar IPA dan ketertarikan berkarir dibidang IPA. Perbandingan sikap yang diberikan oleh tiap kecamatan menunjukkan bahwa tiap indikator tidak memiliki keterkaitan yang

\section{DAFTAR PUSTAKA}

Akinbobola, A. O. (2009). Enhancing Students' Attitude Towards Nigerian Senior Secondary. Australian Journal of Teacher Education, 1-9.

Astuti, Rina., Sunarno, Widha., Sudarisman, Suciati. (2012). dari 272 siswa). Data di atas secara keseluruhan menunjukkan dari 3 indikator Kecamatan Kumpeh memiliki persentasi kendala yang tinggi terdapat pada indikator ketertarikan menambah waktu belajar IPA dan ketertarikan berkarir di bidang IPA

berkesinambungan satu sama lainnya. Faktor lain yang menjadi penghambat adalah adanya perkembangan teknologi yang sangat cepat. Dengan teknologi siswa tidak perlu membaca buku lagi, serta dengan adanya penemuan robot dan alat-alat yang mampu membantu kerja manusia. Siswa juga menjadi malas dan keinginan untuk berkarir dibidang IPA juga menurun. Seperti menjadi ilmuwan, bekerja di laboratorium, menjadi guru maupun dosen IPA, dan lain sebagainya. Selain itu, anggapan mereka bahwa pada jenjang pendidikan yang lebih tinggi maka pelajaran IPA makin sulit dan untuk mencapai cita-cita berkarir di bidang IPA memerlukan waktu yang cukup lama.

Pembelajaran Ipa Dengan Pendekatan Keterampilan Proses Sains Menggunakan Metode Eksperimen Bebas Termodifikasi Dan Eksperimen Terbimbing Ditinjau Dari Sikap Ilmiah Dan 
Motivasi Belajar Siswa. Jurnal Inkuiri. 51-54.

Bang, E., \& Baker, D. R. (2013). Gender differences in Korean high school students' science achievements. Mevlana International Journal of Education, 1.

Chairunnisa, (2017), Meningkatkan Motivasi Dan Hasil Belajar Siswa Konsep Hidrokarbon Dengan Menggunakan Model Pembelajaran Cooperative Script Berbantuan Media Adobe Flash Pada Siswa Kelas XI MIA-3 MAN 3 Banjarmasin Tahun Pelajaran 2016/2017. Jurnal PTK dan Pendidikan, 3: (2) 1-9.

Chopra, V., \& Chabra, S. (2013). Digantar In India: A Case Study For Joyful Learning. Journal of Unschooling and Alternative Learning, 29-43.

CRUMB, C. R., MOORE, C., \& WADA, A. R. (2010). Who Wants to Have a Career in Science or Math? Exploring Adolescents' Future Aspirations by Gender and Race/Ethnicity. Science Education, 459-460.

Damanik, P., D. \& Bukit. N. (2013). Analisis Kemampuan Berpikir Kritis dan Sikap Ilmiah Pada Pembelajaran Fisika Menggunakan Model Pembelajaran Inquiri Training (IT) dan Direct Instruction(DI). Jurnal Online Pendidikan Fisika. 19.

Dinatha, N., M. \& Laksana, D., N., L. (2017). Kesulitan Belajar Siswa Dalam Mata Pelajaran IPA Terpadu. Jurnal Pendidikan Dasar Nusantara. 14

Edginton, C., R., \& Chen, P. (2008). Leisure as Transformation. Champaign, IL: Sagamore Publishing.

Fraser, B., J,. (1981). TOSRA: Test of Science-related Attitudes: Handbook: Australian Council for Educational Research
Godwin, B. A., \& Okoronka, U. A. (2015). Attitude And Academic Performance Of Senior Secondary School Students In Physics In Nigeria. International Conference on Education, 499-506.

Guido, R. M. (2013). Attitude and Motivation towards Learning Physics. International Journal of Engineering Research \& Technology (IJERT), 2087.

Hazari, Z., Sonnert, G., Sadler, M., P., Shanahan, C., M. (2010). Connecting High School Physics Experiences, Outcome Expectations, Physics Identity, and Physics Career Choice: A Gender Study. Journal of Research In Science Teaching. 983.

Hacieminoglu, E. (2016). Elementary School Students' Attitude toward Science and Related Variables. International Journal of Environmental \& Science Education, 36.

Hartinah, S., \& Setiawan, T. (2013). Sikap Guru Taman Kanak-Kanak Terhadap Pembelajaran Matematika. Jurnal Ilmu Pendidikan, 51.

Putri. Physics Experiences, Outcome Expectations, Physics Identity, and Physics Career Choice: A Gender Study. Journal of Research In Science Teaching. 983

Hofstein, A., \& Naaman, R. M. (2011). High-School Students' Attitudes toward and Interest in Learning Chemistry. international year of chemistry [attitude toward chemistry], 90-91.

Indriati. (2012). Meningkatkan Hasil Belajar IPA Konsep Cahaya Melalui Pembelajaran ScienceEdutaiment Berbasis Media Animasi. Jurnal Pendidikan IPA Indonesia. JPPI. 192.

Kaya, H., \& Boyuk, U., (2011). Attitude Towards Physics Lessons And Physical Experiments Of The High 
School Students. European $J$ of Physics Education, 23.

Kena Ismail. (2016). Determination of Motivation of 5th Grade Students Living in Rural and Urban Environments towards Science Learning and their Attitudes towards Science-technology Course. Journal of Education and Training Studies. 155.

Kerlinger, F, N. (2014). Foundations Of Behavioural Research. Yogyakarta: Gadjah Mada University Press

Liaghatdar, M. J., Soltani, A., \& Abedi, A. (2011). A Validity Study of Attitudes toward Science Scale among Iranian. International Education Studies, 36-46.

Nasr, A. R., \& K, A. S. (2011). Attitude towards Biology and Its Effects on Student's Achievement. International Journal of Biology, 100.

Nordin,. \& Ling. (2011). Hubungan Sikap Tehadap Mata Pelajaran Sains Dengan Penguasaan Konsep Asas Sains Pelajaran Tingkat Dua. Journal of Science \& Mathematics Educational. 98.

Owen, S. V., Toepperwein, M. A., Marshall, C. E., Lichtenstein, M. J., Blalock, C. L., Liu, Y., et al. (2008). Finding Pearls: Psychometric Reevaluation of the Simpson-Troost Attitude Questionnaire (STAQ). Science Education, 1007.

Putri, S., Candiasa, M., I., Marheani, N. (2014). Pengaruh Implementasi Metode Pembelajaran Inkuiri Terbimbing Berbasus Asesmen Kinerja Terhadap Hail Belajaran IPA Ditinjau dari Sikap Ilmiah Siswa Kelas VIII SMP Negeri 1 Tegalalang. E-Journal Program Pascasarjana Universitas Pendidikan Ganesha. 2.
Rensi., Sugiarti, L., R. (2010). Dukungan Sosial, Konsep Diri, Dan Prestasi Belajar Siswa SMP Kristen YSKI Semarang. Jurnal Psikologi. 149.

Sakariyau, A. O., Taiwo , M. O., \& Ajagbe, O. W. (2016). An Investigation on Secondary School Students' Attitude. Journal of Education and Practice, 125.

Sitotaw, B., \& Tadele, K. (2016). Students attitudes towards physics in primary and secondary schools of Dire Dawa City administration, Ethiopia. World Journal of Educational Research and Reviews, 1-8.

PELL, A. W. (1985). Enjoyment and Attainment in Secondary School Physics. British Educational Research Journal, 130.

Turkmen, L. (2013). In-service Turkish elementary and science teachers' attitudes. Science Education International, 438-442.

Veloo, A., Nor, R., \& Khalid, R. (2015). Attitude towards Physics and Additional Mathematics Achievement. International Education Studies, 35-37.

Wenno, I., H. (2010). Pengembangan Model Modul Ipa Berbasis Problem Solving Method Berdasarkan Karakteristik Siswa Dalam Pembelajaran di SMP/MTS. Cakrawala Pendidikan. 176.

Widiadnyana I W., Sadia I W. dan Suastra I W. (2014). Pengaruh Model Discovery learning Terhadap Pemahaman Konsep IPA dan Sikap Ilmiah Siswa SMP Tahun Pembelajaran 2013/2014. Ejournal program pascasarjana Universitas Pendidikan Ganesha Program Studi IPA, 2-3.

Widoyoko, E. P., (2016). Teknik Penyusunan Instrumen Penelitian. Yogyakarta : Pustaka Pelajar.

Zanaton., Halim, L., Osman, K. (2006). Sikap Terhadap Sains dalam 
Jurnal Tarbiyah: Jurnal Ilmiah Kependidikan

Vol. 7 No. 2. Juli - Desember 2018 (93-108)

Kalangan Pelajar Sains eli

Peringkat Menengah dan

Matrikulasi. PertanikaJ. Soc. Sci.

\& Hum, 143. 